Гончар Л. О., к.е.н., старший викладач Павлюк Д. М., студентка

Київський національний університет культури і мистецтв м. Київ, Україна

DOI: https://doi.org/10.30525/978-9934-26-036-0-3

\title{
КОНЦЕПТУАЛЬНО-ОРГАНІЗАЦІЙНІ ЗАСАДИ ФУНКЦІОНУВАННЯ РЕСТОРАННОГО БІЗНЕСУ В УМОВАХ ПАНДЕМІЇ COVID-19
}

В сучасних умовах переходу України та світу до карантинних обмежень, через пандемію, спричинену вірусом SARS-CoV-2, в кожній галузі відбувається пошук нових шляхів і методів функціонування, виробництва і реалізації продукції та послуг. Здійснюється аналіз сучасного стану, окреслюються перспективи 
на майбутнє. Ці процеси характерні безпосередньо для сфери готельно-ресторанного бізнесу, яка спрямована на отримання прибутку через надання різноманітних послуг у вигляді харчування та організації дозвілля і відпочинку.

Сучасний стан розвитку та «виживання» готельно-ресторанного бізнесу в умовах карантинних обмежень під час пандемії характеризується незвизначеністю, так званим колапсом і потребує нових креативних ідей та ефективних управлінських рішень. Ресторанний бізнес відрізняється від усіх інших видів бізнесу специфічними особливостями, нерозривністю виробництва, надання і споживання послуг, цілковитою i безпосередньою залежністю прибутковості і рентабельності бізнесу від ефективної і прямої комунікації із гостями (споживачами).

Саме тому, зазнавши досить болючого (подекуди «смертельного») удару пандемією COVID-19, заклади ресторанного бізнесу втратили близько 70\% звичного прибутку на ринку. Від початку карантину у березні обіги ресторанів впали на $81 \%$ в порівнянні 3 докарантинними показниками. Влітку ресторанному бізнесу вдалося відновитися, проте 3 середини жовтня обіги знову знизились.

Відповідно поряд із традиційними способами, видами i методами обслуговування гостей заклади ресторанного бізнесу змушені були вишукувати «рятівні жилети», щоб хоч якимось чином утримати бізнес та забезпечити його функціонування.

Одним із таких «жилетів» виявилась послуга доставки. За даними Glovo, український ринок доставки виріс у 2020 році в 6-7 разів. Заклади, у яких не було послуги доставки, були вимушені запровадити іiі, адже це хоч якось допомогло утримати певний відсоток прибутку [10]. Проте завдяки доставці ресторани можуть забезпечити не більш як 10-30\% звичайного обороту. У бізнесі цього вистачає хіба для того, аби окупити ставки заробітної плати кухарів, які працюють на зміні.

Аналізування результатів опитування рестораторів щодо впливу карантину на стан та розвиток послуги доставки в закладах ресторанного бізнесу, ініційованого і проведеного 
брокерською компанією «БізРейтинг» (BizRating) через телеграмканал «Поговорим о ресторанах» (налічує близько 2400 учасників), дозволяє дійти висновків про те, що наразі послуга доставки надається у більш ніж половині (56\%) підприємств ресторанного бізнесу. При чому $35 \%$ респондентів зазначили, що на іiі впровадження та розвиток значно вплинула поточна кризова ситуація, спричинена пандемією COVID-19. Ще 11\% опитаних розглядають доставку, як один із напрямів подальшого удосконалення ефективності бізнес-процесів та підвищення рентабельності бізнесу в цілому і готові найближчим часом запроваджувати таку послугу у своїх закладах. Однак, 33\% респондентів відзначили, що все-таки послуга доставки це не їх напрям роботи і не планують розвиватися в цьому ключі [2; 3].

Ще одним із напрямів «порятунку» бізнесу виявилось масове $\mathrm{i}$ неминуче скорочення штату ресторанів. Так, більшість закладів вимушені були скоротити штат працівників задля економії та можливості «триматися на плаву». Для власників ресторанів $\mathrm{i}$ кафе проблема виявилась не тільки в утриманні персоналу, але і в підтримці його лояльності. За даними сайту rabota.ua у половини працівників ресторанного сектора дохід знизився, а залишився колишнім лише у близько 18\%. Приблизно у 10\% закладів знижені бонуси і надбавки персоналу. Тільки у 7\% роботодавців потреби в наборі персоналу залишилися такими ж, як $\mathrm{i}$ до введення карантинних обмежень [5].

В цілому за перших два місяці карантину ресторанний бізнес втратив приблизно 12 тисяч підприємств 330 тисяч легально зареєстрованих в Україні, що складає 40\%. До епідемії експерти ринку оцінювали його обсяги приблизно в 1,15 млрд. доларів США, при цьому загальна кількість закладів по країні оцінювалося в 15-16 тисяч, 3 них близько 1800 столичні. Після пом'якшення карантину не відкрилося приблизно 15\% ресторанів Києва.

Попри тяжкі часи та ризик, на ринку ресторанного бізнесу 3'являються нові заклади, власники яких діють за принципом: криза створює можливості на ринку - двері, що зачиняються для 
одних, обов'язково відчинять інші. Так, із середини 2020 року в столиці було відкрито кілька десятків нових ресторанів. При цьому, з іншого боку, в середині цього ж 2020 року було закрито сотні закладів, серед яких багато раніше досить успішних і відомих.

Наразі ресторатори та готельєри обережно i неквапливо планують розвиток бізнесу. Їх увага сконцентрована на тому, яким чином «вижити» сьогодні в умовах, що склалися i y проблемах, що можуть з'явитися найближчим часом.

Провідні фахівці-практики ресторанного бізнесу вважають карантин найбільшою кризою в історії українського ресторанного бізнесу. Навіть не так: ресторатори підкреслюють, що криза - це коли щось буксує, коли $є$ проблеми, а зараз в ресторанному бізнесі усе просто зупинилося. I досить складним, а головне невідомим, $є$ процес виходу із ситуації, що склалась.

Значного удару для діяльності закладів ресторанного бізнесу також завдав «карантин вихідного дня», адже більша частина виручки ресторанів (а саме близько 60-80\%) припадає саме на вихідні дні. Кафе i ресторани втратили 27\% від обігу через «карантин вихідного дня». У суботу та неділю ресторани заробляють в середньому 41\% від свого тижневого обороту, бари - 40\%, піцерії й кальянні - 35\%, фастфуд - $31 \%$, кондитерські - 30\%.

Нищівним для ресторанного бізнесу виявився i період «локдауну», який ресторатори назвали «карантинним локдауном ресторанного бізнесу та індустрії дозвілля і розваг». Але, зважаючи та те, що більшість суб'єктів господарювання в ресторанному бізнесі зареєстровані і працюють як ФОП, частина iз них мала можливість скористатись одноразовою підтримкою від держави, яка в умовах пандемії є особливо актуальною для малого та середнього бізнесу. Для того, щоб скористатися такою допомогою (у сумі 8 тис. грн.), підприємцям необхідно було сформувати і подати електронну заявку через державний портал електронних послуг «Дія» або у мобільному застосунку в період 3 14 до 21 грудня. Дана програма була організована за підтримки та 
ініціативи Президента України (законопроєкт президента № 4429 про одноразову фінансову допомогу для українців), і прийнята Урядом [8; 9].

За інформацією Міністра розвитку економіки, торгівлі та сільського господарства України Ігоря Петрашка підтримка бізнесу 3 боку держави під час карантину відбувається за кількома програмами одночасно. Зокрема за програмою «Допомога ФОПам і працівникам - 8000 грн» ще до нового року виплачено 3,6 млрд грн. (що охопило близько 455 тис. осіб із 480 тис. осіб і складає 95\% від загальної кількості звернень). За програмою «Допомога роботодавцям - до 8000 грн» роботодавцям виплачено 650 млн грн для близько 170 тис. їх працівників. Крім цього підприємцям надана компенсація по ЄСВ на суму понад 200 млн грн [1]. У своїй доповіді міністр також зазначив про те, що «на період карантину послаблено податкове навантаження на бізнес, вдосконалено програму «5-7-9», впроваджено новий інструмент портфельних гарантій, реалізується цілий комплекс заходів щодо боротьби 3 безробіттям» [1].

Поряд із частковою державною підтримкою бізнесу (хоч i незначною, і не для всіх) під час карантину, не зважаючи на діючі обмеження та мораторій на перевірки, для закладів ресторанного бізнесу звичним став постійний моніторинг (перевірка) відповідними органами державної влади на предмет дотримання ними спеціальних санітарно-гігієнічних вимог щодо функціонування підприємств ресторанного бізнесу в умовах дії карантинних обмежень. Відповідно до статті 40 Закону України «Про забезпечення санітарного та епідемічного благополуччя населення», на виконання пункту 4 постанови Кабінету Міністрів України від 09 грудня 2020 року № 1236 «Про встановлення карантину та запровадження обмежувальних протиепідемічних заходів 3 метою запобігання поширенню на території України гострої респіраторної хвороби COVID-19», спричиненої коронавірусом SARS-CoV-2», до закладів ресторанного бізнесу було встанов- 
лено посилені санітарно-гігієнічні вимоги, які в цілому можна розділити на чотири групи [6; 7]:

- загальні вимоги до функціонування закладу, які повинна забезпечити адміністрація підприємства;

- вимоги до персоналу;

- вимоги до організації обслуговування на виніс та/або на відкритих літніх майданчиках;

- вимоги до організації обслуговування в приміщенні закладу.

Згубним для ресторанного бізнесу наслідком карантинного року стало і те, що сотні тисяч людей по всій країні тимчасово чи назавжди втратили роботу, а відповідно це призвело до зниження рівня життя та зменшення витрат населення. Дані дослідження, ініційованого Європейським банком реконструкції та розвитку, яке проводилося у восьми країнах з тих, яким він допомагає та в шести більш розвинених країнах Свропи, свідчать про наступне: 67,5\% українських респондентів відповіли, що фінансовий стан їхніх сімей погіршився через кризу; 15,9\% опитаних українців заявили, що втратили роботу; 10,7\% - що їх відправили в тимчасову відпустку без збереження зарплати; 26,6\% - що їм довелося закрити сімейний бізнес [4].

Також учасники опитування відповіли на ряд питань у напрямку зміни та коригування власних витрат у період пандемії. Згідно з результатами, 26,2\% українських респондентів почали витрачати менше на їжу, 43,5\% - на предмети розкоші, 24,9\% на алкоголь, а 16,8\%, почали менше користуватися автомобілем. $21,5 \%$ респондентів відзначили, що їм довелося пропустити візит до лікаря, 20,7\% прострочили платіж за комунальні послуги, $20,4 \%$ позичили гроші у друзів або родичів [4].

Після закінчення карантину проблеми не зникнуть. Багатьом закладам ресторанного бізнесу доведеться змінювати формат, шукати додаткове фінансування або скорочувати витрати, а головне - боротись за відвідувачів, яких точно стане менше.

За оцінками самих рестораторів третина підприємств цієї сфери після закінчення карантину не відновить свою роботу, 
вони вже фактично банкрути, і ця цифра збільшується щодня загрозливими темпами. Насамперед, це стосується закладів харчування в невеликих містах України, де фінансові можливості і власників, і місцевих споживачів відрізняються від столичних не в кращий бік. Відповідно це свідчить про те, що сотні закладів по всій країні не відчинять двері після скасування карантинних заходів. За попередніми прогнозами після карантину 25\% малого бізнесу не відкриється зовсім, а решта буде в боргах.

Після зняття карантину прогнозується значне скорочення кількості гостей, а відтак зовсім інша виручка й нові фінансові моделі. Звичні відпрацьовані бізнес-моделі вже не будуть ефективними, а на ринок чекає нова культура споживання та нова система бізнес-відносин. На цьому етапі починається нова ера функціонування та розвитку ресторанного бізнесу.

Вже сьогодні ми розуміємо, що ринок ресторанних послуг не буде таким, як раніше. Зміняться пріоритети гостей, ціни, формати закладів в цілому та номенклатура їх послуг зокрема, а також багато іншого. Напевно, будуть затребувані більш прості, зрозумілі, бюджетні історії. Зростуть також вимоги до сервісу. Ніхто не буде сприймати просто їжу як їжу - «всі і всім наситяться вдома». Перед рестораторами окреслюється досить складна проблема формування унікальних в своєму роді послуг, що можуть стати «фішкою» саме їх закладу і таким чином залучати нових гостей та розвивати свій бізнес у інноваційному напрямку і ключі.

\section{Література:}

1. Ігор Петрашко розповів про дієвість програм підтримки бізнесу на час карантину. URL: https://www.kmu.gov.ua/news/igor-petrashko-rozpoviv-pro-diyevist-program-pidtrimki-biznesu-na-chas-karantinu (дата звернення 01.02.2021).

2. Как эпидемия коронавируса повлияла на столичный рынок купли - продажи бизнеса. Рестораны, кофейни, стритфуд Киева. URL: https://bizrating.com.ua/3/articles/1182/index.html (дата звернення 16.01.2021).

3. Как работает бизнес доставки еды. URL: https://bizrating.com.ua/6/ articles/1395/index.html (дата звернення 16.01.2021).

4. Коронавірус в цифрах. Telegram-канал. URL: https://t.me/corona_numbers (дата звернення 16.01.2021). 
5. Прозора робота. URL: https://rabota.ua/ua/prozora?keyword=\&cityId= 0\&rubricId (дата звернення 16.01.2021).

6. Про встановлення карантину та запровадження обмежувальних протиепідемічних заходів з метою запобігання поширенню на території України гострої респіраторної хвороби COVID-19, спричиненої коронавірусом SARSCoV-2. Постанова Кабінету Міністрів Украӥни від від 09 грудня 2020 р. № 1236. URL: https://www.kmu.gov.ua/npas/pro-vstanovlennya-karantinu-ta-zaprovadzhennya-obmezhuvalnih-protiepidemichnih-zahodiv-1236-091220 (дата звернення 01.02.2021).

7. Про забезпечення санітарного та епідемічного благополуччя населення. Закон України (Відомості Верховної Ради України (ВВР), 1994, № 27, cm. 218). URL: https://zakon.rada.gov.ua/laws/show/4004Text (дата звернення 01.02.2021).

8. Рада прийняла закон Зеленського про 8 тисяч допомоги ФОПам $\mathrm{i}$ найманим працівникам. Украӥнська правда: Економічна правда. 4 грудня 2020. URL: https://www.epravda.com.ua/news/2020/12/4/668825/ (дата звернення 01.02.2021).

9. 8 тисяч ФОПам i найманим працівникам: Держава виплатила 3,6 мільярда - Шмигаль. Українська правда: Економічна правда. 4 січня 2021. URL: https://www.epravda.com.ua/news/2021/669735/ (дата звернення 01.02.2021).

10. Сервіс доставки Glovo. URL: https://glovoua.com (дата звернення 16.01.2021). 